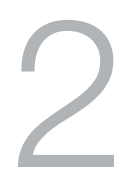

\title{
The Dynamics of Return Migration in Vietnam's Rural North: Charity, Community and Contestation
}

\author{
Nguyen Thi Thanh Binh
}

This chapter tells the story of a return migrant in Bắc Đồng, ${ }^{1}$ a village in Hà Nam Province of northern Vietnam where I carried out extended anthropological fieldwork in the late 2000s. ${ }^{2}$ From my first days in this village, I had heard stories about a rich village woman living in Hồ Chí Minh City whose life and career had become legend. According to these stories, she had been one of the richest people in Sài Gòn in the 1980s and 1990s, a room in her house was sometimes full of money, and hundreds of workers were under her command. People in the village had different ideas about this lady's path to success and the way she exercised her power. In some ways, she was magical for them. Even her name, Núi, evoked a sense of mystery about her life.

\footnotetext{
1 People and places in this chapter have been assigned pseudonyms for purposes of confidentiality.

2 This chapter draws upon ethnographic research conducted in Bắc Đồng village, Hà Nam Province from July 2007 to May 2008. While living with and taking part in the villagers' everyday lives, I interviewed and collected life histories from a wide range of villagers, including my main interlocutor, who I met at her home in Hồ Chí Minh City. I am grateful to Bà Núi and Bắc Đồng villagers for sharing their experiences, insights and time with me. I would like to thank Philip Taylor for his extensive feedback on chapter drafts, and thank Ben Kerkvliet, Hy Van Luong, John Kleinen, Andrew Kipnis, Diana Glazebrook, and the two anonymous readers for their constructive comments. Harvard-Yenching Institute and the Research School of Pacific and Asian Studies, The Australian National University, provided funds for this research.
} 
In Vietnamese, Núi means mountain, and people imagined that she was a mountain of money. Moving to the south in 1975 after the American war, Núi maintained contact with the village through her family and a number of migratory villagers who went to work in or visited her enterprise. Since the 1980s, she had sometimes sent gifts to her relatives and made small donations to the poor, and larger donations for village affairs. Bắc Đồng people's memories and imaginings about Núi and her life in the south might have ceased there if, at the end of 2007, this mythical woman had not suddenly visited her old home after almost 20 years. Her return became an event in the village. People were curious about the way she looked, how she treated the surrounding people, and what she did in their village. They wanted to touch and get up close to this powerful figure who had returned from a far away and prosperous world. Núi aroused in the villagers various expectations and hopes.

Initially, Núi planned to stay in Bắc Đồng for a short time to fulfil her obligations to her family and ancestors. As people learned that Núi was happy to see them, however, more and more villagers gradually came to visit her. In response to the sentiment of her homeland fellows, Núi decided to stay longer, give more gifts to people, and donate more money to renovate ritual places in the village. Her 'heart' of giving to the village's spiritual places and to the poor generated debate among the villagers as to whether she represented a new model of personhood and ethics, or standard of behaviour for the local elite and the rich. Some Bắc Đồng people, especially women, wanted to build a new kind of patron-client relationship with Núi, and for a period of time it seemed that a new inclusive community of villagers, reliant on her generosity, was emerging. This dynamic interaction saw Núi give more in response to the villagers' warm reception and she began to imagine the village as a welcoming and intimate home in which she might find a place after decades of living far away. The story did not end well, however, as envy and criticism from a part of the village population undermined the trust and warmth of these relationships, dashing the dreams and hopes of all parties in these interactions. Chastened and confused, the protagonist Núi returned to her southern, urban home, perhaps never again to return to her home village.

The somewhat tragic story of Núi sheds light on the phenomenon of return migration. As a fertile terrain for migration studies, the experiences of Vietnamese migrants who return home have been 
examined by several scholars. ${ }^{3}$ The comparative literature shows that return migration may, in some instances, be viewed as the outcome of a failed migration strategy or, conversely, as satisfaction of one's original economic or cultural goals (Cassarino 2004:255). Return migration may enable one to reinvest one's migratory earnings in a place where one has a comparative advantage, or convert them into forms of social or cultural capital that may not be attainable in the migratory destination (Bourdieu 1986; Carruthers 2002). Some studies emphasise the factors that 'push' migrants to return home: the hardship and stress of life as a migrant; poor health or personal crisis; or the legal, institutional, and cultural obstacles to integration in the migratory destination (Brettell 2000:100). Alternatively, migrants may be 'pulled' home by homesickness, family crisis, or out of a sense of familial obligation (Gmelch 1980; Jellema 2007). The return home can be conflict-laden and mutually disappointing, both from the perspective of the returnee and their kin and neighbours. Returnees may be the focus of admiration, envy or mistrust from neighbours and kin owing to their exotic status, their relative wealth or practices of conspicuous consumption (Khater 2001). The gifts borne by returned migrants may accentuate social distance between giver and receivers or communicate uncomfortable messages about status differentials just as readily as they might inspire sentiments of belonging and relatedness (Hung Cam Thai 2014; Nguyen-Akbar 2014). Migrants who return home to rural settings may feel torn between their 'old' insider status (with the weight of kin obligations this entails) and their 'new' status as an outsider or stranger, as well as between the pleasure of belonging to a close-knit community and the loss of autonomy that a return to rural living entails (Phillips and Potter 2005; Laoire 2007). Elements of each of these strands can be identified in Núi's story, which can be profitably explored to shed light on the meanings of home and of return for those Vietnamese migrants who have re-engaged with their homelands.

The phenomenon of return additionally casts into relief the circumstances of those who remain at home. Núi's home of Bắc Đồng is a rice-growing village in the southern part of the Red River Delta of Vietnam. Located in a marshy area of the delta where the soils are poor

3 See, for instance, Carruthers (2002), Jellema (2007), Dang Nguyen Anh et al. (2010), Hung Cam Thai (2014), and Nguyen-Akbar (2014). 
and people struggle to make a living, the village has been the recipient of various rural development programs to increase connectivity, improve irrigation, increase rice yield, teach new trades, and diversify livelihoods. Nevertheless, at the time of my fieldwork in 2007-08, only 30 per cent of households in the village were considered well off, because they had made the switch from farming to non-farming livelihood activities. The majority of villagers lived at subsistence levels and about 10 per cent of households were categorised as poor (most of these households comprised elderly occupants). Migration has been the most common local livelihood strategy over time. Such journeys began in the late 1960s, with official population transfers to the uplands, and most recently migrants have flowed to urban and industrial zones in Hà Nội, Huế and Hồ Chí Minh City in search of jobs as industrial labourers and following small business opportunities. One of the most significant waves of out-migration occurred in the late 1970s, shortly after national reunification, as a stream of villagers flowed to the 'promised land' of southern Vietnam. As one of the pioneers of this southwards movement, Núi was an ambivalent figure. The business she set up in the prosperous urban south served as a bridgehead for her fellow villagers and earned her prestige for helping them to escape the poverty and hardship of their home village. Yet during her visits home when she dispensed lavish gifts, the villagers were both awed and disconcerted at the discrepancies between their own humble circumstances and the fortunes of this plump, white and wealthy stranger.

The fervent hopes and intense disappointments unleashed by Núi's controversial return home demonstrate how local sociocultural expectations powerfully shape the meanings and trajectory of return migration. Pertinent in this regard is the complex malaise that had taken root in her home village in the decades since her departure. Characterised by a sense of confusion and marginalisation, these sentiments can be linked to the dislocations experienced by the villagers during the transition to the market economy. Núi's fellow villagers had witnessed the retreat of the socialist state from a formerly all-encompassing social support role and the loosening of social bonds brought about by the disestablishment of collectives, the rise of individualistic economic competition, and the steady outflow of migrants. Not coincidentally, the same period saw the eruption of a number of new religious movements in the village, with many villagers 
placing their confidence in mediums, fortune tellers, faith healers, and in prophets who envisaged the prospective return of a saviour figure. These movements, which were widespread in the Red River Delta in the market integration era, ${ }^{4}$ held out the promise of social restoration and cosmic re-integration to villagers who had been dislocated and disoriented by rapid sociocultural change. It was within this turbulent context that Núi's return home took place. The manner in which some villagers construed her as an almost otherworldly figure is indicative of the messianic expectations that structured her home visit. The envy, insidious rumours and blatant criticism she and her followers attracted also show the status and value conflicts and enmity that characterised life in the village. Not surprisingly, these powerful and contradictory sentiments put this return migrant on course for a stormy homecoming.

This chapter discusses the hopes and fears that the people of Bắc Đồng village invested in a returned wealthy migrant. By investigating responses to her prodigious charitable giving, it explores what local people made of her identity, life and motives for giving, and how they used her activities to reconstruct and critically re-imagine their relationships to each other. I show that in the context of new and old forms of social differentiation, elderly women and the poor in the village construed this village returnee as a Buddha-hearted person and turned her into a patron of the village community. The community of veneration that coalesced around this wealthy returned migrant sparked conjecture and controversy - unleashing status and value conflicts and generating a debate about the ethics of her charitable giving. The warm sentiments precipitated by her return visit momentarily inspired in Núi dreams of reconnecting permanently to her homeland, but ultimately the conflicts it provoked resulted in a homecoming that was temporary and mutually disappointing.

\section{Mysterious Rich Woman}

Like other people in the village, I was curious to know what Núi looked like. In the first days of her visit, only close relatives and people who had received her gifts and donations came to visit Núi at her brother's

4 See, for example, Đỗ Quang Hưng (2001) and Nguyễn Quốc Tuấn (2012). 
house. Others were curious but reluctant to approach her to avoid being misunderstood as 'catching the rich to be relatives' ('thấy người sang băt quàng làm họ'). They waited until they knew more about how she treated people. Gradually, they learned from each other that Núi behaved nicely and seemed close to everyone. Through her family members, Núi sent a message to all of the villagers that they were invited to come to her house. Many decided to visit her to show their homeland sentiment and take the opportunity to learn more about her. Núi welcomed all of the guests, talking to them a little to see whether she still remembered who they were, what their relationship was to her, or what memory they had of her. Afterward, she often invited visitors to see video tapes and photos of her family life. During that time, Núi told people stories about a prosperous and modern Sài Gòn, and explained the differences between the lifestyle in the south and the north. People were full of admiration when they saw photos of her big house or the imposing wedding party of her son at a five-star hotel in Sài Gòn. Many women found it interesting and exciting to gather at Núi's place in the evening, and they began to visit with increasing frequency.

Each evening, around 20 people gathered at Núi's brother's house. Several elderly women who were relatives and had received gifts from Núi decided to stay with her and take care of her. They cooked, cleaned the house, and gave massages to her, for she had developed rheumatism and experienced difficulty moving about. Núi became a centre of attraction for the villagers, attracting women in particular to gather at her place. However, in interaction and conversations, most villagers appeared self-conscious in front of Núi. People tried to be careful and polite, especially some of the ladies who lived with her and served her. They always addressed Núi respectfully, to the point of fawning over her. Everyone, including myself, became drawn into this hierarchical interaction - more because of Núi's majesty than her gifts or money. Some people who were ranked as elder sisters or aunts in her lineage wanted to greet and talk to Núi in the familiar way that they often did to other village fellows, but they had to change and adjust their mode of address when confronting Núi directly. This was partly because Núi was different from people in the village. To them, she looked white, plump and healthy, and was dressed in beautiful clothes and wore make-up. When some young women in the village saw Núi for the first time, they commented that she was as beautiful as 
a fairy queen that they had seen in a movie. Many people were awed by her regal manner and the decisive way she behaved and talked to them, which reminded them of her status as a business person and boss.

Her return aroused debate among Bắc Đồng people about her fate and wealth. Many villagers linked her success to the favourable orientation of her ancestors' graves. People surmised that someone in her grandparents' generation in the village had been well off and possessed some knowledge of classical Chinese script. He must have consulted a geomancer when building the grave for the ancestors. Some villagers believed that the direction chosen for the grave fortuitously brought success to the daughters of the family only. In Núi's parents' generation, one of her aunts had become the owner of a big farm in Thái Nguyên Province, where many villagers went to find jobs before 1954. Meanwhile, Núi's father had lived an ordinary life in the village. However, Núi's eldest sister advanced no further than becoming a local labourer, like her younger brother. Hence the villagers believed that Núi had a special fate (số) that was different from others. Some believed that the mystery to her fortune lay in her name. Some said that it had been given to her when her parents were evacuated from the village to a mountain to avoid a French moppingup operation during the First Indochina War. Others believed that there must have been a mystically significant reason for her parents to give her that name.

Many villagers explained her career and richness in terms of good fortune (gặ may). Several people believed that when she had moved to the south after 1975, by chance she was able to buy the house of a family who had migrated to America and had found a pot of gold hidden inside. Afterwards, she used this capital to do trading and develop her enterprise. Another hypothesis was that she gained business success by manipulating her husband's reputation. As her second husband had been a southern revolutionary who became a cadre in the north after 1954, people believed that after he returned to Sài Gòn in 1975 he must have acquired a high position in the new government. Núi would then have received many gifts and bribes from people who came to ask for her husband's favour. Also thanks to his power, Núi could easily gain success in her trade and business. 
Given these ideas, Bắc Đồng people rarely used the term 'talented' (gioii) to describe Núi and her career. They tended to emphasise the words 'rich' (giàu) and 'lucky' (may mắn), and believed that many young people were now more talented than her in business. However, they still deeply respected Núi's special qualities. Some villagers told each other that Núi could quickly determine whether a newcomer was trustworthy simply by looking at him/her from a distance. That is why, they said, in her business in the south, Núi liked to see prospective employees face-to-face before offering them work. If they did not appear to her to be reliable and trustworthy, she politely declined to employ them and gave them money to find another job or to return home. When Núi returned to the village, she surprised people with her ability to quickly understand the situation of the people she met. The villagers told each other that she was very 'sharp-witted' (tinh). For all of these reasons, from the first days of her return, many Bắc Đồng people showed their respect to Núi. In all of the meetings or rituals in which she participated, even the village cadres and representatives of the elderly association in the village respectfully addressed her with elaborately polite speech. On the occasion of official rituals at the dinh, the organisers invited her to sit on the same mat as the oldest men. People treated her as a distinguished guest, a daughter of the village returned home. During rituals at her lineage hall, Núi was invited to sit with the lineage elders. People in her lineage showed their happiness at having a daughter like her, who could bring fame to the family. The respectful title Bà Núi (Madam Núi) was used popularly by all Bắc Đồng people regardless of their gender or age.

\section{Her Giving}

Another intriguing aspect about Núi that generated much commentary among the villagers was her status as a generous benefactor. In just a short period of time she gave away an enormous amount of money, becoming one of the most generous patrons the village had ever seen. What is remarkable about this generosity is that it appears not to have been part of her original intentions for her return visit. Instead, it seems to have been elicited in the context of the villagers' interactions with her. 
Like many emigrants in northern Vietnam, the practice of ancestor worship was the critical factor that brought Núi back to Bắc Đồng. As Kate Jellema (2007) has illustrated, in the midst of đổi mới, a quest to 'return to origins' transfixed the entire nation and ancestors exerted a strong pull on modern Vietnamese, wherever they resided. According to her, to 'về quê' (return to the homeland) is a rite, an act of filial devotion, at once expected and demanded, forced and desired (Jellema 2007:58). Following this ideology of northern migrants, which also receives endorsement by the state, Núi initially intended her visit to fulfil her obligations to her family. She simply wanted to build a royal tomb for her parents and ancestors, and a new house for her brother, an ordinary labourer in the village. In this sense, she wanted to share her success with her family and meet her familial obligations.

At the beginning of her visit, Núi gave gifts only to relatives, as is the custom of Vietnamese who return to their homeland. When some poor villagers who had previously received Núi's charity via her family came to thank Núi for her kind heart, she responded compassionately by personally offering them further gifts. Gradually, it became Núi's routine practice - when confronted by relatives to whom she felt she should give something, or by poor and disabled people who had difficult lives - to give 100,000 dồng or more. Her close relatives and the old women who surrounded and served her every day often proposed to whom Núi should give her gifts and advised Núi of the recipients' circumstances. Núi's giving became a popular topic of discussion among the villagers, especially women, as to who had received her gifts.

The local government also decided to approach Núi after several weeks.

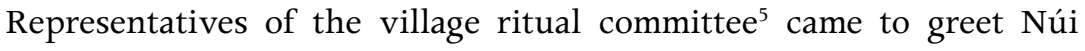
and thanked her for the donation she had sent for the village festival the year before. They invited her to participate in rituals at the dinh (the village communal house). Later on, Khôi - the village head organised a meeting at the dinh to express the gratitude of the village for Núi's previous contribution to village affairs and the poor. Khôi then went on to ask Núi for a donation to his project - already under construction - to rebuild the village road to the temple. In response

5 Like other Vietnamese villages in the Red River Delta, the committee of historical sites, which was later renamed the committee of rituals and festivals (ban khánh tiết), of Bắc Đồng was established in the early 1990s to take care of the village communal house and its rituals. 
to this call and the sentiments demonstrated towards her by the cadres and villagers, Núi decided to contribute 20 million VND (about $\$ 1,000$ USD) for the temple road and 20 million VND to renovate the dinh's floor, which she thought made the temple look dirty and dark. Not long after that, Núi decided to spend another 20 million VND building a road to the ladies' temple to replace a path along the edge of a rice field after the elderly had complained to her about this path and she herself had experienced difficulty walking on it. In addition, Núi brought large quantities of fruit, cake and meat as offerings to the village temple and pagoda on significant occasions. After offering the food to the spirits, she shared it with the elderly, or sometimes with the whole village. By the end of the year, Núi again compiled a list of 60 poor families in the village and gave each of them a total of 30 million VND (about \$1,500 USD) to celebrate the New Year. She also gave scholarships for poor and talented students and bought toys for the village kindergarten.

As Núi gave more and more, she became a hot topic in the daily conversations of the villagers, who paid attention to her every movement. Local cadres and representatives of the elderly association in the village made frequent visits to show their care for her, to present their plans and projects and to discuss village affairs in an attempt to gain her support. Influential people (có máu mặt) in the village, such as those who took care of the followers at the two shrines of the village and some mediums, also often visited Núi to talk to her about the possibility of investing in their groups' ritual interests. All the formal and informal social groups in the village considered Núi as a patron and tried to take advantage of her presence to invite her donations to their cause. Owing to her influence as a donor and her prestige, many villagers also expected her to be able to influence leaders to do a better job at managing the village. A woman recounted with satisfaction an occasion in which Núi had firmly chastised the village head:

Once I heard Núi comment to Mr Khôi, the village head, that: 'You should not be strict about rituals. I myself was seized by the spirits so I shared with the mediums in the village. You should organise an annual festival and not make it bureaucratic. If someone makes a mistake, you should solve their problem yourself instead of sending them up to the commune. I used to manage hundreds of workers and I could solve all their problems.' Khôi could only nod his head. (Mrs Đặng, 68 years old, an elderly small trader and farmer in Bắc Đồng) 
Although Núi denied that this exchange had taken place, circulation of the story indicated that people expected Núi to be able to change or have an influence on their local government. As her house became a centre where people, especially women, brought news of village daily life for discussion, Núi quickly grasped the situation of the village, the concerns of people and gossip about individuals. Some people came to ask her to mediate their personal grievances with other villagers, considering that her experiences of life outside of the village gave her the insight to offer judicious advice.

The esteem and honour that many Bắc Đồng people reserved for Núi encouraged her to give more, and nurture new ideas for the future. During the two months of her first return trip to the village, Núi contacted her family in Sài Gòn several times to order additional gifts and money to be sent to Bắc Đồng, since the level of demand had exceeded her expectation. When I asked them what they thought about her, most villagers said that Núi was ascendant (nổi lên) and venerated (được tôn sùng). The dynamics of the process show that her giving and other activities in the village were the result of an interaction between the demands and sentiments of Bắc Đồng people and her response to them - rather than any intentional plan.

Many women in the village thought that everyone who received something from Núi owed her a debt of gratitude (on), and thus felt compelled to fawn upon her (quỵ luỵ). These explanations by Bắc Đồng people fit with the idea of the gift as an offering that inherently creates in the recipient an obligation to reciprocate (Mauss 1967). In reality, only a few Bắc Đồng people who received many gifts and favours from Núi tried to give her something in return, such as some fresh fruit from their garden or help with her housework. The majority of recipients felt that they could not give any equivalent material gifts in exchange, since Núi did not need anything they could give in return. Therefore, when a person accepted a gift from Núi, they also accepted that they were now indebted to her - but could only repay that debt through the expression of sentiment, respect or submission. Similar to the way that cash gifts given by returned overseas migrants to their relatives in Vietnam impose upon and burden those who receive them (Hung Cam Thai 2014:15), Nui's gifts aroused in her recipients a sense of obligation from which they could not easily extricate themselves. 
Given this, some people in Bắc Đồng, especially the rich who were concerned about their manners (giữ ý), tried to keep their distance from Núi or avoid receiving her gifts. However, as Núi's giving became a phenomenon, most people were interested in receiving a gift which they viewed as a blessed token from a successful returned migrant that had the capacity to bring them joy and fortune. Her generosity to them was considered by many to be the result of their own fate, rather than Núi's own good heart. One old lady, who was the mother of some successful traders in the village and had no special relationship with Núi, told me that since she had witnessed Núi's gifts to many people, she also expected Núi to give her about 100,000 VND, the value of a health tonic that she sometimes took. By the end of Núi's visit, many people said that it was not only individuals who were indebted to Núi but indeed the whole village, for everyone in the village had eaten the pork meat and sticky rice that she had offered to the village deities during festivals and then shared out among the villagers, and on account of everything else she had done for the village. It was clear from their exhilaration that many people felt happy and proud to have been individually touched by her largesse.

Through giving, Núi was able to accumulate status and power. As more and more villagers received gifts from Núi and accepted the responsibility to show their sentiment for her, her prestige continued to rise. Many considered her generosity as the action of a fortunate person sharing with others the blessings (lộc) that she had received from the spirits. Her actions were similar to the wealth distribution practices of potlatch found among indigenous peoples of the American northwest coast, in which chiefs or the rich would build status by hosting lavish feasts and compete to give away food and property (Codere 1950; Jonaitis 1991). Closer to home, Núi's gifts were akin to the gifts distributed by Vietnamese spirit mediums to their following, whose largesse is motivated not simply by altruism or the imperatives of kinship or camaraderie, but by the obligations invested in those enjoying a status as masters - as spiritual patrons in a patron-client relationship (Endres 2011:13-36).

All of the villagers agreed that if Núi had no money or had not given it to people, she would not have been feted in the village. If a person gives only the average amount of charity to help the poor, they will receive esteem no greater than that enjoyed by ordinary people. In Núi's case, besides helping the poor she had also given her heart (tâm) to village 
affairs, thus she received the respect of local government officials and the esteem of the villagers. Before Núi returned to the south to celebrate New Year, Bắc Đồng village held a farewell for her. The event offered an opportunity for the village to evaluate her efforts and think about how to express their gratitude. After many days, at a meeting comprising all of the representatives of the village - the people, government and party (hội nghị dân-chinh-đảng) — Khôi and the village leaders decided to present to Núi a classical Chinese script painting consisting of the word 'tâm', meaning 'heart-mind'. ${ }^{6}$

In his speech at her farewell, Khôi tried to explain the meaning of this word and the reason the village wanted to give the script painting to Núi. Khôi understood tâm as the soul, spirit and heart inside the human person. Whoever had a good heart to do good things would be appreciated and supported by the spirits. However, to make sure that he and the villagers gave this award to Núi with a full understanding of its meaning, Khôi asked for advice from an advisor in Hà Nội, a journalist called Thức. Even though Thức had some knowledge of classical Chinese script and had been researching traditional culture and religion for a long time, he carefully spent several hours checking dictionaries and reference books before answering Khôi's question. He wanted to quote official books and classical texts. During a phone conversation with Thức, Khôi wrote down the meanings of the word that the journalist had summarised from various textbooks. According to his research, the main meaning of tâm was that whoever had a pure heart would be a Buddha. Thức wanted Khôi to emphasise that Núi had a valuable tâm because she helped the poor and gave offerings to the gods without any ulterior motive. Her tâm was not only recognised by human beings but by the spirits. Thus, she and her family would receive 'good fortune' (phúc). In response to this spiritual and meaningful gift, Núi thanked the village for giving her happiness beyond her imagination. Then she elaborated further the meaning of tâm. She explained that in the south she had learned from Buddhist monks that 'tâm is Buddha and Buddha is tâm' (tâm tức Phật, Phật tức tâm). She understood that Heaven and Buddha gave birth to humans, and that Heaven can be characterised by benevolence, righteousness

6 In his analysis of the self in Vietnam, David Marr (2000) defined and translated tâm as 'heartmind', meaning the bearer of inner awareness, sentiment, knowledge and moral judgement. 
and morality (nhân, nghĩa, đạo đức), and behind the meaning of those three concepts is tâm. If a person has tâm, they can achieve anything they want (muốn làm gì là làm được).

These learned discussions about the meanings of tâm suggest that it is a broad and abstract concept. However, in the minds of many villagers with whom I talked, its meaning appeared to be less complicated. People simply thought that Núi had tâm because she believed in spirits, had Buddha in her heart, and tried to give to both living beings and the gods in order to receive good things for herself and family. As Marr (2000:770) notes, unlike most other concepts derived from the Chinese classics, tâm is not bound by hierarchy. The heartmind of even the lowliest person in society is able to commune with other heart-minds, with nature, the spirits, and the universe at large. In the case of Núi, the villagers were compelled to admit that she was good, and gave and contributed to the community on these terms. Although she was not really talented or distinguished in terms of her 'merit' (công) to the country, ${ }^{7}$ she deserved to gain the honour and esteem of the people. One elderly man said that,

People do not esteem her [Núi] so much because of her talent [giỏi], social relationships [quan hệ] or morality [đức] ... but her tâm towards the village affairs. (Mr Lâm, 70 years old)

However, this gift of thanks was enough to make Núi feel happy before returning home to Sài Gòn, ending her first return visit full of passion and emotion. Meanwhile, for many Bắc Đồng people, her visit encouraged them to hope that their own situations and that of the village might continue to improve with ongoing assistance from this extraordinary benefactor.

\section{Her Reasons for Giving}

Although tâm, or heart, was how Núi's motives for giving were interpreted by Bắc Đồng village leaders, it only partially captured Núi's own reasons. For her, the role played by fate was more important. As a person whose life had once been as deprived as those villagers she had helped, and whose prosperity had come unexpectedly, she believed

7 For a discussion of the concept of công, see Jellema (2005). 
that fate had played a crucial role in her success. She intuited that demonstrations of kindness to others might positively influence one's own fate. Additionally, she felt sympathy for people whose circumstances reminded her of her own difficult life. As her business career drew to a close, her health declined and relations with family members in the south became strained, she was particularly receptive to the warm homecoming that she received in Bắc Đồng village. Núi explained her actions with reference to her own life history and it is therefore useful to retell Núi's rags-to-riches story to understand what considerations influenced her actions.

Given her family's poor situation, Núi could attend only the first grade of school before dropping out to stay at home and help her parents take care of her younger brother. When Núi was 16 years old, she started to learn about petty trade. She travelled to northern mountainous provinces such as Thái Nguyên, Yên Bái and Lạng Sơn to practice buying and selling goods. During her trips to Yên Bái, Núi met and married the son of a landlord she often stayed with. One year after the wedding, when Núi was 20 years old, she gave birth to a son. At that time, her parents-in-law asked Núi to live with them and help with farming activities. But Núi disagreed. She decided instead to return to Bắc Đồng village with her four-month-old son. However, her own parents were not happy with her decision and did not invite Núi and her son to live with them in the family home, thus she moved again.

When Núi was 24 years old, on a trip to Thái Nguyên Province she met a southern military cadre who worked in a factory there. He was older than her by 20 years. She decided to marry him, for he was alone in the north while his family lived in Sài Gòn. Núi and her son then moved to live with him in a small apartment in Hà Nội. After she remarried, Núi had more children and became the primary breadwinner when her husband took early retirement soon after marriage. His pension was not enough to support a family in that subsidised period. Thus, she had to do various kinds of work to earn a living, including spinning silk for the ward's embroidery team and selling pork and chicken meat in the grey market (chợ đen). The 10-year period that she lived in Hà Nội — from the mid-1960s to the mid-1970s — was a hard and miserable time for Núi. Apart from economic difficulties, she also suffered from discrimination and prejudice from her family and neighbours about her marital life. She felt devastated when her team leader refused to advance her salary, despite her children being sick in 
the hospital and, on another occasion, when commercial management cadres confiscated 3 kilograms of meat - her whole capital - in spite of her explanation that her husband was a wounded southern soldier and her family was extremely poor. Such incidents made her recall the north as a land of harshness and poverty.

After unification in 1975, Núi followed her husband to Sài Gòn. In the beginning, she just sold fried bananas on the pavement. Later, she followed a friend into a business where she served traders who came from the north by helping to connect them with buyers. Thanks to her husband's position as a ward cadre, his connections, and her own efforts, more and more traders approached her for assistance and Núi earned a substantial income. Every day, several dozen traders resided in her house and sometimes she could earn a tael of gold in a single day. After three years in this business, she bought a big house in the city centre. From that time, Núi emerged as an influential trader in Sài Gòn.

In the early 1980s, her assets totalled more than 50 tael of gold. However, in 1982 Núi lost most of her capital through trading antique furniture. During that difficult period, by chance, a man from Đình Bảng village asked her to help him sell carved wooden furniture. At first, Núi earned a commission by selling the furniture in Sài Gòn but then expanded to Phnom Penh, Cambodia. In 1985, she opened an enterprise in her home to produce carved wooden furniture and by the 1990s she was exporting her products to Japan, Taiwan, and other eastern Asian countries. Included in her 100-strong workforce were around 50 people from Bắc Đồng. Some of them came to Sài Gòn with a letter of recommendation to Núi from their parents or relatives. Others asked relatives in the south to accompany them when they approached Núi for a job.

Núi thought a lot about training craftsmen, and in the mid-1990s she sponsored 10 boys from poor families in Bắc Đồng to learn the craft of furniture making in Nam Định Province. Núi also accommodated some young boys from poor families from Bắc Đồng in her home in Sài Gòn, where they were taught carving skills and, at the same time, sent to a local school to complete their education. Even from a distance, Núi remained connected to her village through such acts of patronage. 
Núi's business thrived in the 1990s, when many of its products were exported. Each month, many container loads of goods were dispatched abroad and car loads of money were transferred back to her house. However, in 1999 her enterprise suddenly came to a halt. The intermediary companies between Núi's company and Japanese and Taiwanese buyers resented the large profits being derived by Núi and responded by establishing rival enterprises and enticing most of Núi's workers to work for them. Thus, her enterprise came to a standstill due to a shortage of labour.

Núi accepted this turn of events quietly and calmly, switching to real estate where she redirected her energy and capital into buying land. She purchased 5,000 square metres of agricultural land in Thủ Đức District, an undeveloped part of the city at that time. The subsequent urbanisation of this agricultural land rendered Núi's investment to be worth around 20 billion VND (close to $\$ 1$ million USD). However, after that deal, her business career again came to a halt and she experienced a series of personal crises.

Since 2000, Núi has been ailing. Her leg developed a kind of rheumatism. She began to walk with a stick and sometimes needed assistance to move about. Her husband also died around that time. Most of her children were incapable of running the business, since they were used to depending on her. Three of them switched to small business, which only provided a subsistence income. The three youngest children continued to receive monthly stipends from their mother. Two of them had become drug addicts by 2008. In 1999, during her most prosperous period, Núi was able to send one of her sons to study in Canada. After graduating he remained in Canada and could have applied for professional employment and citizenship, but his ordinary academic performance led him to work in a field which provided no more than a subsistence income.

Looking back over her life, Núi was proud of her achievements. Although she was not as rich as the richest person in the south, what she had achieved was remarkable, given that she had left her home village and given birth to seven children in poverty. She was respected as a successful business person. It was in relation to her family that she believed she had failed. Extremely preoccupied with her business, Núi had been unable to take care of or teach her children well. Consequently, her children took life for granted and had no capacity 
to work hard as she had done. Núi reflected that the dependence of her children gave her power over them that other richer women do not have; she made all the decisions about the family and her property.

As previously noted, initially Núi planned to go home simply to build a house for her brother and grave for her ancestors before she got older and weaker. But Núi had not imagined how enthusiastically the villagers would welcome her. The emotion of the villagers encouraged Núi to stay longer and give more in the belief that this might be a decision made by the spirits. The spirits had led her back to the north to give and, as had previously happened in her life, they would give her other things in return. Explaining her giving, Núi said that the money gifted was like the blood vessels of the body. She had learnt from Buddha that only someone who cut a blood vessel without feeling hurt would not regret giving away their money. In her case, she did feel hurt but was compelled to do it in order to follow the spirit's call. In addition, Núi accounted for her actions in the village in terms of her compassion towards her natal village. Returning and being surrounded by many poor women made Núi feel sympathy for her fellow villagers who were in essence just like her - except for the intervention of fate. Witnessing people suffer hardship and poverty also made her feel less sad about her own family life and reminded her of her own good fortune/luck. Given her strong belief in fate and her sense that she was on the threshold of another major turn in her life, Núi gave liberally in the anticipation that something extraordinary was about to happen.

\section{Contradiction and Misunderstanding}

While Núi's generosity may not have been clearly understood by the villagers, her manner of giving stimulated a great deal of commentary and conjecture. For many Bắc Đồng people, Núi's giving was a strange and extraordinary phenomenon that they had never seen or heard of before. People not only wondered about how Núi had become rich but also about the source of her donations. Some people believed that most of her charitable gifts came from a Canadian charitable organisation. This idea might have derived from her son's residence in Canada, causing people to imagine that she had contact with such a network through him. Some villagers could not believe that she took money 
from her own pocket to give to others. As most knowledge about Núi came from villagers who had either worked for her or visited her in the south, her actions remained mysterious to most people. Even the way she gave surprised the villagers.

When offering charity, Núi carefully considered the situation of the poor to assess whether they genuinely needed help. If she found out that the children or close relatives of the poor people in the village were rich, she would not give them anything. Although hunger and poverty have existed in the village for a long time, Bắc Đồng people found it hard to grasp the concept and practice of charity that Núi introduced. At first, some people were reluctant to receive money from her. In other cases, children of the elderly objected to their parents receiving help. However, people gradually got used to Núi making a record of poor households' situations and her habit of taking documentary photos. She often made a detailed list of households and tried to understand clearly each of their circumstances in order to give them a suitable amount. Her gifts were flexible and fair but also arbitrary. I overheard women telling each other that Núi never gave gifts to people who complained about their difficulties but wore jewellery made from gold.

During her giving, Núi also set conditions on the contributions she made to poverty eradication or construction projects, which potentially threatened the authority of village officials. When Núi decided to give money to all of the poor households in the commune, she asked the local government to give her a list of poor households categorised according to her own criteria, instead of the official criteria and list. When donating money to build the temple road or repair the dinh, she could easily calculate the cost of these works without the assistance of local cadres. People understood that it was difficult to swindle Núi. An elderly man on the ritual committee revealed that the local cadres had felt embarrassed when they calculated that a project to upgrade the road to the Lady's shrine would cost 24 million VND (about \$2,200 USD). With her ability, Núi easily knew that it would cost less than that. But she politely responded that, given her limited budget, she would like to take over the construction work herself to reduce the cost. As a result, she only had to pay 17 million VND. This incident reminded Núi that the local cadres also expected something from her, at least for the time they devoted to village affairs. Núi shocked them when she offered them a gift of 10 million VND. She nicely explained 
that it was a reward for their hard work for the village. The fact was that Núi had to determine who was who in the village and find the best way to live with people. By being involved in the practice of giving, she wanted to help harmonise social relationships in the village.

Returning from a far-away world, Núi brought to Bắc Đồng many new values, most importantly the values of kindness, charity, and 'heartmind'. Some old people said that they had never seen anyone as kind and giving as Núi. The villagers learned that Núi had practiced charity and giving for a long time in the south, where such activity was common. Apart from these charitable practices, Núi also represented a different way of life and thinking. People were surprised that she did not think exclusively about herself, her children, and her family. Núi claimed that whenever confronted with a decision to spend a lot of money on luxurious personal effects or expensive meals in a restaurant, she tried to limit her spending in order to save money for charity. Even though Núi owned property worth about \$1 million USD, none of her children had a big house or expensive car. She gave each of them no more than a fixed monthly stipend. As noted above, Núi built a new house in the village for her only brother, gave him a monthly stipend, and gave other relatives larger and more frequent gifts than outsiders. But she never met her relatives' expectations, giving them just enough to live on and giving more to people who really needed it. By acting in this way, Núi said she could overcome the traditional Vietnamese ideology of 'family first' and think about others as well.

This way of thinking and behaving was strange to the villagers. Núi tried to make people understand that in the outside world, people acted beyond family obligations, beyond the concept of 'amoral familism' (Banfield 1967), and cared about other members of society. In the south, she said, individuals like her could take on the work of caring for the poor or victims of disasters, work that, in the village, was usually regarded as a responsibility of the government. Núi encouraged people to change their minds and act like people in the outside world. She advocated that the poor accept responsibility for their situation and try to overcome their poverty. If a person did not want their close relatives to be ranked as poor, they ought to take care of them and help them to better themselves. Núi criticised as hypocritical the egalitarian and communal discourses in the village by making people aware of the reality of social stratification and urging them to do something about it. She said people should 
love each other more and do more to help people outside their own family. Her advocacy of these values and ways of relating to others generated much debate among villagers as to whether this new form of personhood represented a good model or not.

From the outset, the rich doubted Núi's charitable intentions, claiming her to be motivated by self-interest and querying the morality of her wealth (Jellema 2005:233). Some hypothesised that in the past, Núi must have done something bad or evil to become rich and now she wanted to undertake charity to lessen her guilt. This hypothesis originated either from the idea in contemporary society that to be rich is immoral, or from the experiences of the rich in Bắc Đồng themselves, such as fierce competition among traders, sibling rivalry and fighting, exploitation of labourers, and rampant cheating by traders. Meanwhile, others surmised that Núi gave to have a peaceful heart and to forget about the fact that some of her children were drug users. Nevertheless, even though some rich villagers expressed their doubts about Núi's kindness and morality, they were prepared to admire what she had done for the village.

Some villagers whose children had previously worked for Núi in Sài Gòn ventured the observation that Núi had been a difficult boss. It was said that she favoured people who were clever with their hands and words and bestowed privilege on these, while lazy persons and those who did not know how to please her fell into disfavour. Núi stated that a clear distinction existed between boss and worker in the south. She liked labourers to refer to themselves as 'con' (children) in her presence, and address her formally as ' $b a{ }^{\prime}$ (madam), regardless of how old they were or their kinship relationship with her. Villagers felt compelled to use this respectful mode of address (bẩm bà) in their interactions with her. Some people thought that this approach engendered politeness in villagers, while others thought of it as bossy (hách dịch). Many Bắc Đồng people felt it was difficult to submit to her in that way.

The way Núi had managed her workers in the past became a hot topic of discussion among villagers. It was claimed that her relationship with workers was a strictly patron-client one. It was a begging and giving relationship (xin-cho). She selected labourers carefully and implemented strict contracts and supervision. In order to retain her workers and to help them save money to bring home, Núi paid their full salary only at the end of the year. Every month, she gave them 
a small amount of money to buy necessities for personal consumption. If a worker needed an extra amount, they had to make a special request and provide a good reason. Workers were required to stay within the confines of their houses. Visitors had to seek the guard's permission to contact workers. Despite the fact that her management approach aimed to protect workers from social evils and assist them to save their remittances, many Bắc Đồng migrants decided to leave Núi's enterprise after a certain time. One former labourer who subsequently established his own enterprise compared Núi's management model to colonial-style capitalism. According to him, she exercised authoritarian behaviour (cửa quyền) over others. By contrast, modern young capitalists like him applied a model of 'agreement' (thỏa ước) based on the principle of 'two sides each have profit' (hai bên cùng có lợi). However, many parents in the village admitted that her strict rules had helped their children grow up and be successful.

After Núi came back to the village and began distributing money, some villagers complained about her being bossy and difficult. If anyone needed her help, they had to report to her in the manner of a subordinate (thưa chuyện). Only important persons such as Khôi, the village leader, were received formally by her. Usually, Núi let her nieces or some ladies help her serve tea for the guests. Some villagers did not feel respected when they were invited to sit at the table and talk to her while she was seated on the bed in the next compartment. For some, this arrangement resembled a colonial-era scene whereby the poor or subordinates came to ask favours from landlords or mandarins. It was unclear whether Núi treated people like this because it was her own way or because of her bad leg. Some villagers also questioned her morality since, according to them, Núi did not care enough for her family and relatives in the village. Even though Núi built a big house for her brother and gave him a monthly stipend and gave more to her nieces than to others, whenever she gave gifts to the poor, some of her more distant relatives claimed that she was not treating them fairly. Moreover, it was said she easily got angry and was prone to scold her brother and nieces if they did not follow her orders. As a result, some gossiped about her 'giving but cursing' (cho rồi chửi) without noticing that sometimes Núi felt tired and stressed due to her family members' reliance on her. 
All of these dynamics show that local reaction to Núi's giving was extremely complicated. Most villagers acknowledged their esteem for her as a result of her giving and her 'heart'. Some intellectual men of Bắc Đồng told me that they had observed that it was labourers, who accounted for 60 per cent of the village population, who most welcomed and venerated Núi as their saviour. Her giving, according to those educated people, was like a capitalist giving to the poor. It made the poor feel less unequal and helped send a message to the rich in the community that they should not be selfish; instead, they should be kind and should share and give like Núi. On the other hand, her undisclosed motives and her rational approach to giving aroused controversy and disappointment in many people. Well-off villagers were the group most likely to raise questions: about her motives, her recent business 'failure' in Sài Gòn, her first marriage, and her 'immoral' background. Her failure to privilege her closest relatives served as additional ammunition for some villagers who, perhaps influenced by familial ideology or motivated by envy, used rumour and speculation, and their reserves of time and local connections, to try to cut Núi down for not caring adequately for her own family. Her potlatch-like generosity could not protect Núi from these barbs or put her esteem beyond dispute.

\section{Limits of Giving}

Despite these undercurrents, Núi's first return visit ended happily for both her and the villagers. Village leaders and people kept expecting and hoping that she would take the initiative and the main role in new rebuilding projects. Núi left the village with a vague promise that she would try her best to do more work for the village if the spirits let her. Returning to her big and quiet house in Sài Gòn, she missed the warm atmosphere in the village where she had been esteemed and surrounded by an entourage. Bắc Đồng village was scheduled to hold its festival two months after Núi's return to the south. On behalf of the village, Khôi tried to convince Núi to participate in the event, but Núi hesitated before making a decision. Since closing her furniture enterprise, she derived her main income from land trading but intended to sell most of her property and divide the profit between her children, as an inheritance. She would then keep a part of the profit for herself to enjoy her last days of life and to give to others in 
the form of donations. But, owing to the fall in the property market, she had not yet been able to put her plan into action. Thus, most of the money she had spent on living expenses and for giving had been borrowed with interest. However, the call from Bắc Đồng was so strong that at the last minute Núi decided to borrow more money and fly back to the village. Later on, she disclosed that this decision went against the advice of the spirits. As Núi often consulted with the gods before undertaking any significant action, she went to the temple to pray and ask the spirits whether she should return to Bắc Đồng a second time. ${ }^{8}$ The two coins she cast to obtain the spirit's answer showed that she should not return, but Núi ignored this advice.

Responding to the expectations of the villagers, on her second visit Núi gave even more than she had during her first one. She gave 59 million VND to 59 poor households in the commune to help support their recovery from the coldest winter in recent history. The commune held a big official meeting at a hall to receive this donation. In this meeting, Núi gave a speech about how poor she had been and encouraged people to overcome their difficulties. Later, the district radio station conducted an interview with Núi. Subsequently, she decided to spend a further 100 million VND to rebuild a lotus pond in front of the village temple. During the village festival, Núi offered a big pig and a lot of sticky rice as offerings to the god, and gave the meat to the villagers.

Things became more complicated when Núi decided to buy a house for her own use in the village. She aimed to use it as a place to stay whenever she visited Bắc Đồng. After she died, it would be given to the lineage to use as their ancestor hall. This news caused wide discussion among villagers about whether Núi would stay permanently in the village or not, and why. Her decision reignited gossip that Núi had been forced to return to live in the village because she had gone bankrupt in the south, and because her children had become drug addicts, leaving no one to care for her.

Women in the village expressed excitement about her house purchase, thinking she had decided to return to Bắc Đồng. Some even visited Núi at her new house and asked her if she would stay permanently.

8 Mediums or followers of Tứ Phủ religion often practice 'xin đài' to seek a sign of the spirits' approval by throwing two coins. If they fall head and tails, it means the spirits approve. 
Tired of her living arrangements being the subject of speculation, when two elderly women in the village asked her, 'Is it true that you will live here?', and added, 'Now then, stay here with us', Núi answered angrily: 'My god, do you want me to abandon my children and property? Would you ever do that to your children?!' The two ladies felt ashamed, saddened and surprised by Núi's response to them. They judged Núi's behaviour as improper and said that it showed an authoritarian attitude toward villagers. Explaining this incident, Núi argued that she was countering anyone who spread malicious gossip about her. When the two elderly women shared their version of what happened with others, most Bắc Đồng people showed no response or comment - they were caught between venerating Núi and judging her according to moral norms.

The story became more serious when a daughter of one of the elderly women, Thúy, decided to retaliate. One morning, when Núi was receiving the president of the commune's Women's Union, who had come to convince her to donate to her association, Thúy came to revile Núi with terrible words. Addressing Núi as a selfish old hag (con mu béo), she claimed that Núi was a bad and immoral woman who had more than one husband and had used her wealth to shout at and scold villagers. Núi and the communal cadre sat quietly for an hour while they endured Thúy's verbal abuse. After this incident, Khôi and the village leaders sympathetically offered to send Thúy to the commune authorities for discipline. Many people who held Núi in high esteem came to console her and said that she should not bother about Thúy, that no one in the village wanted to touch Thúy, and that Thúy was a stubborn and undesirable (thành phần bất hảo) woman who had married and then divorced a strange man from the border area where she worked as a petty trader. Returning to the village, Thúy dared to heap insults on and fight with anyone. She even abused her own mother. However, in this case she wanted to defend her mother to redeem her own status. Commenting on what happened, the head of the village Elderly Association explained that when a person emerges as an economic power there will always be some who envy them. Further, no one dares to touch those with political power but people dare to abuse those with other powers, implying that economic power is not as strong as political strength. This incident made those who venerated Núi feel a bit discouraged. On the one hand, they were worried that Núi might abandon her role as patron. On the other hand, 
they did not want to get involved in a debate about their patron's morality, which had been questioned by some people who doubted her kindness and 'heart-mind'.

Around this time, Núi's relationship with family members in the village also soured. Her children in Sài Gòn never complained or intervened in Núi's donations. They had grown used to her practice of giving and charity in the south. However, when she returned to Bắc Đồng the second time, she met many objections from her close relatives and family in the village. While Núi had intentionally given more to her brother, sister, nieces and nephews than to outsiders in order to keep their relationship on a good footing during the first trip, family members now expressed disappointment and discontent when they compared what they had received with what outsiders were given. They wanted to receive much more than just stipends or small investments from her. They complained to their neighbours, and many villagers questioned whether Núi cared more about outsiders than her own siblings. Since her gifts could not reach all relatives and villagers, she also received subtle reminders from some distant relatives that she had forgotten to give to them. During the festival, when a woman who was possessed by the spirit at the Lady's temple saw Núi, she said obliquely that 'there is someone [she meant Núi] who only takes care of outsiders and neglects descendants and relatives'. Núi was perceptive enough to understand immediately that this woman's mother was one of her cousins to whom she had not yet sent greetings or a gift. Núi immediately arranged to send something to this cousin.

Things took a turn for the worse after Núi departed the village the second time. Two of her nieces abused some elderly women who had been staying with Núi in order to take care of her. Her nieces wanted these women to stop serving Núi in order to assume this task (and its rewards) for themselves. This incident led Núi to believe that her family in the village was hindering her work of giving and her good reputation. Subsequently, Núi phoned me and during our hour-long conversation she confessed her fear that people in the village would no longer come to her and that her entourage would abandon her. Núi called for my urgent help to mobilise her surrounding followers and encourage them to believe that she was able to handle what was happening. Núi's confession demonstrated to me that she was worried about losing the new identity and status that had been created through her interactions and acts of giving to the people and community. 
After the incidents mentioned above, the villagers began to openly discuss Núi's popularity. Some men disliked and disagreed with the way many women in the village 'bootlicked' (bợ dố) and fawned upon on Núi. They criticised those ladies who looked after Núi more respectfully and carefully than they would their own mothers. It seemed that those men did not want to see manifestations of inequality and economic power in their community. Meanwhile, on their visits home or through their families, some successful young business people from Bắc Đồng working in Sài Gòn and abroad made it known, perhaps brashly, that they could do more giving than Núi in the near future. A competitive spirit emerged among other rich migrants from the village who claimed that they too could attain the kind of esteem and power held by Núi. At home, competitive young people working as traders also raised objections to the idea of venerating Núi, or indeed any rich person.

Following these interactions, Núi reflected sadly, 'homeland is a bitter fruit' ('quê hương là quả đắng'). ${ }^{9}$ Thúy's public scolding reminded her that people still remembered her past. The story of her miserable impoverishment in Hà Nội, her record of more than one husband, and marrying an older man and becoming his second wife were still recalled by people. It felt to Núi that her attempts to acquire a higher reputation in the village were the subject of obstruction and challenge, and that the villagers had not changed - northern people were still narrow-minded, selfish and envious. Their thoughts were extremely hard (tư tưởng nặng nề). The rich were despised and the poor disdained. While the villagers were talented, they were not prosperous and not happy due to their narrow-mindedness and limited horizons. After returning again to the south, Núi saw the northern delta as a place with limited prospects for development owing to its restricted area and poor markets. Núi reappraised southern people as broadminded, tolerant and easy-going. Their hearts were like that of Heaven (lòng người như lòng Trời).

Nevertheless, from the remove of her home in the south, Núi persisted in safeguarding the esteem she had earned in her natal village. She pressured family members to continue giving to her followers in

9 Most Vietnamese are familiar with the famous line of poetry 'quê hương là chùm khế ngọt' ('homeland is a bunch of sweet star fruit'). In contrast, Bà Núi experienced homeland as a bunch of bitter fruit. 
line with her previous plans. To patch things up at the village level, Núi thought about building a big gate for the dinh and repairing the pagoda. However, these ideas could not be implemented as Núi was unable to sell her property due to the economic recession.

During that time, Núi chose to invite me to her house in Sài Gòn. She did not hide her aim of using me as a tool to remedy gossip about her in the village. Núi told me she thought that the villagers trusted me and would believe in what I saw and told them about her life in the south. She arranged several meetings for me with some of her children. She took me to visit one of the most famous temples in Sài Gòn where she was highly esteemed, and one of the biggest pagodas in the city where the master monk received her warmly and respectfully. She wanted to demonstrate that her wealth was real, that her children were under her command and taking care of her, and that the most honourable places and people in the south held her in esteem and acknowledged her good character. I felt nervous about Núi's expectations of me and wondered what I should tell the villagers about her life in the south. To my surprise, however, when I returned to Bắc Đồng, no one in the village asked me about my trip. I tried to mention my journey and Núi to encourage questions but the villagers tended to ignore my attempts. I wondered if they were trying to avoid debate or simply wanted to forget the sad story of a person in whom they had invested a lot of hope but who had become a lightning rod for contention and disappointment in their village.

\section{Conclusion}

The controversies surrounding this Vietnamese return migrant's efforts to reconnect with her home village offer revealing insights into the complex dynamics that shape homecomings and other projects of reconnection in migratory societies. In some respects, her return visit was in no way out of the ordinary, motivated at it was by a desire to return to her homeland to acquit her filial obligations at the end of a difficult working life that had brought both success and failure. Nevertheless, the direction and eventual outcome of her return journey was unpredictably shaped by the force of the imagination and the dynamics of class differentiation and status. The expectations invested by Bắc Đồng villagers in this rich return business migrant set her on a 
new course of helping the whole village and diverted her efforts away from her original intention to assist her own family. The difficulties villagers had in comprehending and contextualising her actions led to misunderstanding, conflict, and eventual mutual disappointment.

We can learn much from this story of conflicted return through the lens of social drama (Turner 1974), and by drawing out the perspectives of each of its key protagonists. Núi's own story shows that, like many migrants in northern Vietnam, she originally wanted to return to fulfil her culturally prescribed obligation to her ancestors (Jellema 2007). Return migration theorists might describe this motivation as the satisfaction of a migratory strategy, one that responded to the cultural 'pull' factor of familial obligation (Gmelch 1980; Brettell 2000; Cassarino 2004). However, what she encountered in her natal village made Núi feel sympathy and compassion for those suffering poverty and misery as she had in the past. She saw herself in her fellow villagers and this inspired her to give much more widely than familial obligation alone would dictate was necessary. Her emotional rediscovery of the village as a home in which she was esteemed was both epiphany and consolation for Núi, who had experienced harshness, hope and disappointment as a migrant trader under the socialist subsidy period, and again in a later phase of life as an urban capitalist trader. However, the reasons for her generosity were misunderstood and resulted in contradictory social, emotional and intellectual reactions. Instead of eliciting gratitude, her actions aroused envy and criticism among fellow village elites. In the end, the community of sentiment that had coalesced around her collapsed, brought down by the very familial ideology that had drawn her home in the first place.

In the context of increasing social differentiation in this rural setting, many of Bắc Đồng's poorest people spontaneously venerated this wealthy returned migrant and incited her to become a patron of the village. Many elderly women in particular aspired to form a community surrounding her, reliant on her generosity. Infused with sentiments of solidarity, mutual obligation and hierarchy, this following provided a space of refuge - not dissimilar to that provided by Buddhist pagodas or mediumistic followings in the northern delta - for people marginalised by the ideology of the patrilineal household (Luong 2006:382-383; Endres 2011:13-36). The villagers' construction of this homecoming migrant as a miraculous being also shows the important role of the religious imagination in creating a 
space of hope for the marginalised in the rural north. Conceptions of Núi as a Buddha-hearted person, a bringer of blessings, or a fairy queen illustrate the spiritual aspirations attached to her charitable acts. The village leadership also sought to acknowledge her contributions in these terms when they commended her as a 'heart-minded' person. Nevertheless, criticisms directed towards this spontaneous community of veneration also reveal the existence in rural northern villages of a vein of scepticism towards spiritual-based hierarchies that may derive from, or indeed pre-date, the ideological reforms of the high socialist era (Malarney 2003; Taylor 2007:29-36). The controversial homecoming ended in mutual disenchantment between Núi and the people who had expected so much of her. The story shows the power of the imagination and the limits of that power in the constitution of community in contemporary Vietnam.

The homecoming also provoked a number of ethical conflicts. One of the most heated stemmed from the familialist ideology of the village. Although motivated by a sense of filial reciprocation and the obligation to support her less fortunate family members, Núi's giving quickly escalated to include all manner of non-family members. As such, she was motivated by the universalistic ethics of Buddhism and an explicit critique of the orientation of 'amoral familialism' (cf. Banfield 1967) that limits ones sphere of ethical responsibility to the family. However, her behaviour was noted as an ethical violation by family members. Their objections to her generosity cannot be seen merely as examples of individual opportunism or greed, for this critique of her neglect of family members was voiced widely by other villagers, suggesting that she was in contravention of a more generalised norm. Núi's bewilderment at her fall from favour and the sweeping contrast she drew between the 'open-hearted' character of the south and the 'narrowness' and 'hardness' of the north can be read as a fundamental conflict between different ethical systems: the familycentric ethics of her northern rural birthplace and the Buddhist, modernist and capitalist ethics internalised during her long sojourn in the urban south.

A second plank of familialist ideology that became a source of contention were the traditionalist norms of feminine submission, fidelity and sacrifice (Ngo 2004; Pettus 2004). When Núi spoke harshly to a pair of elderly women, Núi suddenly found herself on trial by village gossips for her lack of wifely fidelity, and her inadequacies 
as a mother. In turn, her most vocal accuser was quickly silenced on the grounds that she too was severely lacking in feminine virtue. Núi shared these values, for it was her sensitivity to the implication that she had willingly abandoned her children that had caused her to speak out harshly against her elderly village dependants. Underlying all these attacks was an ideology of feminine submission. Women who asserted themselves too forcefully in public were prone to being disparaged as lacking in core feminine virtues. No amount of good will generated by Núi could immunise her against this assault on her character. Indeed, the very act of giving made her vulnerable to this angle of attack, for villagers themselves posited links between her wealth and her infidelity, and her generosity and her lack of support for her own children. These attitudes suggest that traditional gender ideologies continue to be mobilised to discipline women's involvement in the rural public sphere in northern Vietnam, for it was Núi's very influence and stature that made her vulnerable to the charge that she lacked feminine virtue.

The final set of serious conflicts was provoked by the challenge that Núi's charitable acts represented to local structures of authority and status in the village. Intriguingly, for this wealthy capitalist from the south, the elites who responded most warmly to her charity were the members of the village party and state administration. They hoped, perhaps naively, that her wealth could be channelled to support their village reconstruction projects, thereby elevating their own status. However, older educated villagers and men in particular objected to her sudden cult-like status on two grounds. The first was that it flowed almost entirely from the money she had accumulated from her business dealings, and hence did not connote talent or morality, indeed quite possibly the reverse. In these respects their critique of her status could be tied to the long-standing stigmatisation of commerce noted in northern Vietnamese rural communities (Malarney 1998). Second, they resented what they saw as a bossy and high-handed manner. In these respects she challenged status hierarchies in the village that prioritised age seniority, learning, and male gender. ${ }^{10}$ Criticism directed at Núi's dealings with villagers may have reflected the

10 For an extended discussion of these hierarchies elsewhere in the rural Red River Delta, see Luong (2010:62-80). 
influence of socialist ethics as much as a traditional discomfort for raw displays of great power and wealth. In short, her actions humiliated a section of the village elite, whose status was derived from tradition.

A different group of elites who resented her approach were Núi's fellow new rich. They did not so much resent her method as her success at it. These fellow elites were conflicted, for although she represented a new model of personhood and ethics for the local rich, she also represented a competitor. Their aspirations to outdo Núi in charitable prowess signify that this village is becoming an arena for status conflicts based on new criteria of externally derived wealth. Her case thus illustrates the complex terrain on which claims to status operate in contemporary northern Vietnamese villages. Although this wealthy migrant's charitable giving created new hierarchies between herself and marginalised village members, such hierarchies were unstable and prone to elicit contestation on both traditional and modern grounds. As such, this case reveals that far from merely enveloping all participants in warm sentiments of solidarity and concord, the charitable practices of returned migrants also have the capacity to promote invidious social comparison and dissension within rural communities, and to inflict harm on both charitable donors and recipients alike.

\section{References}

Banfield, Edward C. 1967, The Moral Basis of a Backward Society, The Free Press, New York.

Bourdieu, Pierre 1986, 'The Forms of Capital', in John Richardson (ed.), Handbook of Theory and Research for the Sociology of Education, Greenwood, New York, pp. 241-258.

Brettell, Caroline 2000, 'Theorizing Migration in Anthropology', in Caroline Brettell and James Hollifield (eds), Migration Theory: Talking Across Disciplines, Routledge, New York and London, pp. $148-174$.

Carruthers, Ashley 2002, 'The Accumulation of National Belonging in Transnational Fields: Ways of Being at Home in Vietnam', Identities: Global Studies in Culture and Power, vol. 9, no. 4, pp. 423-444. 
Cassarino, Jean-Pierre 2004, 'Theorising Return Migration: The Conceptual Approach to Return Migrants Revisited', International Journal on Multicultural Societies, vol. 6, no. 2, pp. 253-279.

Codere, Helen 1950, Fighting with Property: A Study of Kwakiutl Potlatching and Warfare, 1792-1930, Augustin, New York.

Dang Nguyen Anh, Tran Thi Bich, Nguyen Ngoc Quynh and Dao The Son 2010, Development on the Move: Measuring and Optimizing Migration's Economic and Social Impacts, Viet Nam country report, GDN and IPPR.

Đỗ Quang Hưng 2001, 'Hiện Tượng Tôn Giáo Mới: Mấy Vấn đề Lý Luận và Thực Tiễn' ['New Religious Phenomena: Theoretical and Practical Issues'], Tạp Chí Nghiên Cứu Tôn Giáo [Religious Studies Review], vol. 5, pp. 3-12.

Endres, Kirsten 2011, Performing the Divine: Mediums, Markets and Modernity in Urban Vietnam, NIAS Press, Copenhagen.

Gmelch, George 1980, 'Return Migration', Annual Review of Anthropology, vol. 9, pp. 135-159.

Hung Cam Thai 2014, Insufficient Funds: The Culture of Money in LowWage Transnational Families, Stanford University Press, Stanford.

Jellema, Kate 2005, 'Making Good on Debt: The Remoralisation of Wealth in Post-Revolutionary Vietnam', The Asia Pacific Journal of Anthropology, vol. 6, no. 3, pp. 231-248.

Jellema, Kate 2007, 'Returning Home: Ancestor Veneration and the Nationalism of Đổi Mới Vietnam', in Philip Taylor (ed.), Modernity and Re-enchantment: Religion in Post-revolutionary Vietnam, ISEAS Publications, Singapore, pp. 57-89.

Jonaitis, Aldona (ed.) 1991, Chiefly Feasts: The Enduring Kwakiutl Potlatch, University of Washington Press, Seattle.

Khater, A. 2001, Inventing Home: Emigration, Gender and the Middle Class in Lebanon, 1870-1920, University of California Press, Berkeley. 
Laoire, Caitríona Ní 2007, 'The "Green Green Grass of Home"? Return Migration to Rural Ireland', Journal of Rural Studies, vol. 23, no. 3, pp. 332-344.

Luong, Van Hy 2006, 'Structure, Practice and History: Contemporary Anthropological Research on Vietnam', Journal of Vietnamese Studies, vol. 1, no. 1-2, pp. 371-409.

Luong, Van Hy 2010, Tradition, Revolution, and Market Economy in a North Vietnamese Village, 1925-2006, University of Hawaii Press, Honolulu.

Malarney, Shaun Kingsley 1998, 'State Stigma, Family Prestige and the Development of Commerce in the Red River Delta of Vietnam', in Robert Hefner (ed.), Market Cultures: Society and Morality in the New Asian Capitalisms, Allen and Unwin, St Leonards, pp. 268-289.

Malarney, Shaun Kingsley 2002, Culture, Ritual and Revolution in Vietnam, University of Hawaii Press, Honolulu.

Malarney, Shaun Kingsley 2003, 'Return to the Past?: The Dynamics of Contemporary Religious and Ritual Transformation', in Hy Van Luong (ed.), Postwar Vietnam: Dynamics of a Transforming Society, Rowman and Littlefield, Boulder, Colorado, pp. 225-256.

Marr, David 2000, 'Concepts of "Individual" and "Self" in TwentiethCentury Vietnam', Modern Asian Studies, vol. 4, no. 34, pp. 769796.

Mauss, Marcel 1967, The Gift, W. W. Norton \& Company, New York.

Ngo Thi Ngan Binh 2004, 'The Confucian Four Feminine Virtues (Tu Duc): The Old Versus the New - Ke thua Versus Phat huy', in Lisa Drummond and Helle Rydstrøm (eds), Gender Practices in Contemporary Vietnam, NUS Press, Singapore, pp. 47-73.

Nguyen-Akbar, Mytoan 2014, 'The Tensions of Diasporic "Return" Migration: How Class and Money Create Distance in the Vietnamese Transnational Family', Journal of Contemporary Ethnography, vol. 43, no. 20, pp. 176-201.

Nguyễn Quốc Tuấn 2012, 'Về Hiện Tượng Tôn Giáo Mới' ['On New Religious Phenomena'], Tạp Chí Nghiên Cứu Tôn Giáo [Religious Studies Review], vol. 1, pp. 11-15. 
Pettus, Ashley 2004, Between Sacrifice and Desire: National Identity and the Governing of Femininity in Vietnam, Routledge, New York and London.

Phillips, Joan and Robert Potter 2005, 'Incorporating Race and Gender into Caribbean Return Migration: The Example of Second Generation "Bajan-Brits"', in Robert Potter, Dennis Conway and Joan Phillips (eds), The Experience of Return Migration: Caribbean Perspectives, Aldershot, Ashgate.

Taylor, Philip 2007 'Modernity and Re-enchantment in Postrevolutionary Vietnam', in Philip Taylor (ed.), Modernity and Reenchantment in Post-revolutionary Vietnam, ISEAS Publications, Singapore, pp. 1-56.

Turner, Victor 1974, Dramas, Fields and Metaphors: Symbolic Action in Human Society, Cornell University Press, Ithaca. 
This text is taken from Connected and Disconnected in Viet Nam: Remaking Social Relations in a Post-socialist Nation, edited by Philip

Taylor, published 2016 by ANU Press, The Australian National University, Canberra, Australia. 